\title{
MODEL KONTRADYKTORYJNEGO PROCESU KARNEGO W ŚWIETLE NOWELI DO K.P.K. Z 27 WRZEŚNIA 2013 R.
}

Ustawa z 27 września 2013 r. o zmianie ustawy - Kodeks postępowania karnego oraz niektórych innych ustaw wejdzie w życie 1 lipca 2015 r. Głównym celem tej nowelizacji jest przemodelowanie postępowania jurysdykcyjnego: z systemu inkwizycyjnego ${ }^{1} \mathrm{w}$ kierunku większej kontradyktoryjności oraz takie przemodelowanie postępowania przygotowawczego, które pozwalałoby na prowadzenie rozprawy kontradyktoryjnej. Założenia te - zdaniem autorów omawianego projektu ${ }^{2}$ - mają usprawnić i ograniczyć przewlekłość procedowania w sprawach karnych przez redukcję czynności dowodowych w toku postępowania przygotowawczego, której towarzyszyć ma zwiększenie w postępowaniu sądowym inicjatywy dowodowej stron. Od lat bowiem w doktrynie podnosi się, że obecny model postępowania przygotowawczego wprowadza niejako prymat etapu przedsądowego wobec rozprawy głównej, co jest zjawiskiem niepożądanym ${ }^{3}$. Współczesny model postępowania przygotowawczego krytykowany jest także dlatego, że z jednej strony nie zapewnia stronom swobody w dostępie do akt sprawy oraz udziału w czynnościach dowodowych, z drugiej zaś - zakłada duży wpływ ustaleń poczynionych w tym stadium postępowania na późniejsze ustalenia dokonywane przez sąd ${ }^{4}$. Problem ten jest istotny, ponieważ przepisy Kodeksu postępowania karnego nie zawieraja żadnych dyrektyw pozwalających na wartościowanie poszczególnych dowodów. Nie można zatem przyjąć, że większą wartość dowodową aniżeli dowody przeprowadzone w postępowaniu przygotowawczym maja dowody przeprowadzone przez sąd.

\footnotetext{
${ }^{1}$ Nowela zrywa z sowieckim modelem postępowania, przyjętym przez polskiego ustawodawcę z powodów politycznych w latach 1949-1950. Szerzej o tym: B. Bieńkowska et al., Wykład prawa karnego procesowego, Białystok 2012, s. 19; S. Waltoś, P. Hofmański, Proces karny. Zarys systemu, Warszawa 2013, s. 126; J. Koredczuk, w: System prawa karnego procesowego, t. 1, cz. 1, red. P. Hofmański, Warszawa 2013, s. 357-364.

${ }^{2}$ Uzasadnienie „Projektu ustawy o zmianie ustawy Kodeks postępowania karnego i niektórych innych ustaw przygotowane przez Komisję Kodyfikacyjną Prawa Karnego”, dostępne na: http://ms.gov.pl.

${ }^{3}$ P. Kruszyński, M. Warchoł, Pozycja sędziego na tle modeli postęowania przygotowawczego, cz. 1, „Palestra” 2008, nr 3-4, s. 49-50; P. Kruszyński, M. Zdrojewska, Nowy model postepowania karnego ukształtowany nowela do k.p.k. z 27 września 2013 r., „Palestra” 2014, nr 1-2, s. 55 i n.

${ }^{4}$ P. Kruszyński, M. Warchoł, op. cit., s. 49-50.
} 
Wydaje się, że ustalenie najsłabszej strony obecnego modelu postępowania w sprawach karnych daje gwarancję, że wprowadzone zmiany będą zmierzały w dobrym kierunku. W szczególności trudno nie zgodzić się z tym, że główne założenie przyjętej nowelizacji, sprowadzające się do wyeliminowania dublowania w postępowaniu sądowym czynności dowodowych przeprowadzonych już w postępowaniu przygotowawczym, jest zmianą zadowalającą. Podobnie należałoby ocenić środek służący usunięciu tej dwutorowości, polegajacy na zwiększeniu roli kontradyktoryjnego wyjaśniania faktów sprawy przed sadem. W mojej ocenie, przyjęcie takiego założenia nie mogło polegać na czymś zgoła innym aniżeli na ograniczeniu czynności dowodowych oskarżyciela w postępowaniu przygotowawczym. Zgodnie z tym ostatnim ukierunkowaniem ustawa wprowadza zmianę w treści art. $297 \S 1$ pkt 5 k.p.k., modyfikując zadania postępowania przygotowawczego odnośnie do zbierania i zabezpieczania dowodów. Nowa treść tego przepisu nakłada na oskarżyciela obowiązek zebrania dowodów tylko w niezbędnym zakresie - pozwalającym na przygotowanie skargi oskarżycielskiej ${ }^{5}$. Tym sposobem ustawodawca osiagnął główne - a zarazem słuszne - założenia nowelizacji, redukując zakres czynności dowodowych w postępowaniu przygotowawczym ${ }^{6}$. Słuszne jest spostrzeżenie, że zmiana ta spowoduje, że postępowanie przygotowawcze prowadzone będzie dla prokuratora, co jest normą we współczesnych ustawodawstwach europejskich, a nie dla sądu, co było założeniem modelu sowiecko-komunistycznego ${ }^{7}$.

Jednocześnie nowy model opiera się na założeniu, że inicjatywa dowodowa, a w konsekwencji - odpowiedzialność za wynik postępowania, zostaje przerzucona $\mathrm{z}$ sądu na strony. Takie rozwiązanie urzeczywistnione ma być nowa treścią art. 167 k.p.k., który zakłada, że we wszystkich postępowaniach przed sądem wszczynanych z inicjatywy strony procesowej (dotyczy to postępowań po wniesieniu zarówno publicznego, jak i prywatnego aktu oskarżenia) inicjatywa dowodowa należeć będzie do stron. W uzasadnieniu projektu ustawy zmieniającej Kodeks postępowania karnego wskazuje się nawet, że sąd powinien pełnić rolę jedynie „biernego arbitra, który po przeprowadzeniu przez strony dowodów, uprzednio wnioskowanych przez strony i dopuszczonych

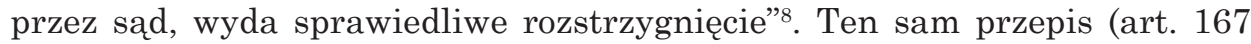
$\S 1$ k.p.k.) stanowi jednak, że sąd będzie mógł wprowadzić dowód do procesu „jedynie w wyjątkowych, szczególnie uzasadnionych wypadkach”. Jakkolwiek więc sąd zwolniony będzie z obowiązku „poszukiwania” dowodów potwierdza-

${ }_{5}^{5}$ Nowela art. $297 \S 1$ pkt 5 k.p.k., który określa cele postępowania przygotowawczego, otrzymuje brzmienie: „zebranie, zabezpieczenie i w niezbędnym zakresie utrwalenie dowodów w zakresie niezbędnym do stwierdzenia zasadności wniesienia aktu oskarżenia, albo innego zakończenia postępowania, jak również do przedstawienia wniosku o dopuszczenie tych dowodów i przeprowadzenia ich przed sądem".

${ }^{6}$ W doktrynie można jednak spotkać pogląd, że zmiany dotyczące tego etapu postępowania robią wrażenie pozornych. Dlatego też postuluje się przeprowadzenie gruntownej zmiany w tym zakresie. Zob. R. A. Stefański, O nieadekwatności projektowanych zmian w zakresie postepowania przygotowawczego do proponowanego modelu rozprawy głównej, w: P. Wiliński (red.), Kontradyktoryjność w polskim procesie karnym, Warszawa 2013, s. 225-233.

7 P. Kruszyński, M. Zdrojewska, op. cit., s. 59.

8 Uzasadnienie Projektu o zmianie ustawy..., s. 9. 
jących skargę oskarżycielska, w sytuacji gdy oskarżyciel publiczny tego nie zrobi $^{9}$, to jednak nowe rozwiązanie nie pozbawia w zupełności sądu inicjatywy dowodowej w sytuacji pasywności strony. Nowy model procedowania w sprawach karnych przewiduje zatem model niezupełnej kontradyktoryjności, ale ten jego aspekt należy ocenić pozytywnie. Trudno bowiem wymagać innego rozwiązania w sprawach, w których spór prowadzi z jednej strony przedstawiciel interesu państwa, z drugiej zaś - jednostka. W tym względzie słuszna jest uwaga P. Hofmańskiego, że: „Oskarżyciel, za którym stoi aparat państwa, ma nie tylko szerokie możliwości pozyskiwania dowodów, ale także wprowadzania ich do procesu. Obrona ma te możliwości drastycznie ograniczone"10. W doktrynie spotkać można jednak przeciwników tego rozwiązania. W ich przekonaniu tylko model pełnej kontradyktoryjności, w którym sąd nie ma możliwości dopuszczenia dowodu z urzędu, pozwoliłby na osiagnięcie wszystkich założeń reformy, albowiem „tylko wtedy stanie się tak, że prokuratorzy będą musieli sprostać oczekiwaniom, które nakłada na nich nowa ustawa procesowa"11. Mimo wszystko wydaje się, że racje przemawiające ostatecznie za pozostawieniem inicjatywy dla sądu sa bardziej przekonujące. Nie można jednak odmówić słuszności tym, którzy obawiają się, że brak dobrego przygotowania do sprawy stron może być kłopotliwe ze względu na kolejność, w jakiej zadawane będą pytania osobie przesłuchiwanej w przypadku dowodu przeprowadzanego przez stronę, dlatego że członkowie składu orzekającego uprawnieni będą do zadawania ich w ostatniej kolejności. Uniemożliwi to bowiem przesłuchującemu zorientowanie się co do ewentualnego zakresu pytań, co niewątpliwie byłoby możliwe po uprzednim wysłuchaniu tych zadawanych przez sąd ${ }^{12}$.

Wiadomo, że takie rozwiązanie przyjęte jest już w postępowaniu cywilnym, które już od jakiegoś czasu jest postępowaniem kontradyktoryjnym. Nowy model postępowania karnego idzie jednak o krok dalej, wprowadzając jeszcze dodatkowy aspekt tej kontradyktoryjności. Artykuł 370 k.p.k. w nowym kształcie wprowadza bowiem zasadę, że dowody przeprowadzane są przed sądem przez stronę, na wniosek której został on dopuszczony. W związku z tym to strona występujaca $\mathrm{z}$ wnioskiem dowodowym nie tylko w pierwszej kolejności będzie zadawała pytania osobom przesłuchiwanym, ale także do jej obowiązków należeć będzie np. przedstawianie dowodów rzeczowych przed sądem. Zapis ten, zdaniem autorów projektu, ma służyć zmotywowaniu stron (a więc także oskarżyciela) do aktywnego uczestniczenia w postępowaniu dowodowym, pod rygorem utraty możliwości przedstawienia sądowi swoich racji ${ }^{13}$. Tymcza-

9 Uzasadnienie Projektu o zmianie ustawy..., s. 10.

10 P. Hofmański, Model kontradyktoryjny w świetle projektu zmian k.p.k. z 2012 r., w: P. Wiliński (red.), op. cit., s. 34.

11 M. Gutowski, głos w dyskusji nad referatem: T. Grzegorczyka, Sytuacja procesowa stron $w$ kontradyktoryjnej rozprawie $w$ świetle projektu zmian k.p.k. z 2012 r., zawartym w publikacji pokonferencyjnej P. Wiliński (red.), op. cit., s. 59.

12 J. Giezek, głos w dyskusji nad referatem T. Grzegorczyka, Sytuacja procesowa stron w kontradyktoryjnej rozprawie w świetle projektu zmian k.p.k. z 2012 r., ibidem, s. 64.

13 Uzasadnienie Projektu ustawy o zmianie ustawy..., s. 11. 
sem należy zwrócić uwagę, że w kontradyktoryjnej od lat procedurze cywilnej wszelkie dowody zgłoszone przez strony przeprowadza jednak sąd, a nie jak zakłada to nowy model postępowania karnego. Ponadto na gruncie Kodeksu postępowania cywilnego sąd może przeprowadzić dowody z urzędu, może także zmieniać lub uzupełniać wydane wcześniej postanowienia dowodowe (art. 232 zd. 2 i art. 236-241 k.p.c.). Z tego względu wprowadzone rozwiązanie jest poniekąd dyskusyjne, aczkolwiek trudno sobie wyobrazić, by w praktyce właśnie w tym zakresie - dochodzić miało do różnicy pomiędzy postępowaniem w sprawach karnych a cywilnych.

Co do inicjatywy dowodowej sądu nowy model postępowania zakłada, że sąd będzie mógł przeprowadzić dowód z własnej inicjatywy jedynie w wyjątkowych, szczególnie uzasadnionych wypadkach (art. 167 § 1 k.p.k.). Nowela nie wprowadza jednak żadnych sankcji procesowych za nieskorzystanie przez sąd z inicjatywy dowodowej (art. $427 \S 4$ k.p.k.). Sąd nie będzie więc miał obowiązku poszukiwania dowodów potwierdzających skargę oskarżycielską i winę oskarżonego w sytuacji, gdy oskarżyciel tego nie zrobi. Należy zatem zauważyć, że z uwagi na obowiązującą zasadę domniemania niewinności, w praktyce to od zaangażowania oskarżyciela zależeć będzie ostatecznie rozstrzygnięcie. I tu pojawia się największa niedoskonałość nowego modelu procedowania w sprawach karnych. Okazuje się bowiem, że zmianom w procedurze karnej nie towarzyszą - pożądane nawet w środowisku prokuratorskim - zmiany w ustawie o prokuraturze ${ }^{14}$ i Regulaminie prokuratorskim ${ }^{15}$. Może zatem okazać się, że faktycznie prokuratura nie będzie w stanie sprostać modelowi pełnej kontradyktoryjności. Środowisko to swoje obawy wyraziło w Opinii Rady Głównej Związku Zawodowego Prokuratorów i Pracowników Prokuratury RP, w którym wskazuje się, że prokuratura nie jest przygotowana do zmian w procedurze karnej, właśnie ze względu na obecna strukturę organizacyjna i zasady funkcjonowania (s. 9 i n. Opinii). Z punktu widzenia obecnego ustroju prokuratury to zasada jej jednolitości może stać się najważniejszą przyczyną niepowodzenia. Zgodnie bowiem z tą zasadą prokuratorzy mogą zastępować się wzajemnie w prowadzonych postępowaniach, a sytuacja, w której prokurator sporządzający akt oskarżenia pełni następnie w tej sprawie funkcje oskarżyciela przed sądem, jest rzadkością. Dodatkowo nowa treść art. 332 § 2 k.p.k. zwalnia oskarżyciela z obowiązku sporządzania uzasadnienia aktu oskarżenia i tym samym nie będzie stanowić ułatwienia dla prokuratora biorącego udział w rozprawie głównej. Słuszna co do zasady kontradyktoryjność może więc w praktyce sprowadzać się do aktywności jedynie jednej strony procesowej, albowiem trudno wymagać aktywności procesowej od prokuratora nieznającego sprawy i nieponoszącego służbowej odpowiedzialności za jej wynik?

$\mathrm{Z}$ powodu powyższych niedoskonałości nie do przyjęcia jest wysunięty ostatnio postulat całkowitego odstapienia od możliwości dopuszczania dowodów przez sąd na niekorzyść oskarżonego. Zdaniem autora tej myśli: „Nie ma

14 Ustawa z 20 czerwca 1985 r., Dz. U. 1985, Nr 31, poz. 138.

15 Rozporządzenie Ministra Sprawiedliwości z 24 marca 2010 r. „Regulamin wewnętrzny urzędowania powszechnych jednostek organizacyjnych prokuratury”, Dz. U. 2010, Nr 49, poz. 296. 
żadnych powodów, by Sąd sanował z urzędu niezdolność organów państwa do obrony stawianego obywatelowi zarzutu karnego. Jeżeli zaś policja, prokuratura, a także liczne pozostałe służby dysponujące szerokimi uprawnieniami dochodzeniowo-śledczymi, nie są w stanie dowodzić swych racji przed sądem, bez pomocy sędziego, wypada zastanowić się nad kondycją nie tylko tych organów, ale także kondycją całego państwa"16.

W tym względzie należy rozważyć, czy ze względu na powyższe słabości polskiego wymiaru sprawiedliwości uda się pogodzić zasadę kontradyktoryjności z naczelną zasadą procesu karnego, jaka jest zasada prawdy materialnej (art. 2 § 2 k.p.k.). Jak podnosi się w uzasadnieniu projektu, może się wydawać, że sąd, który zdany jest na dowody prezentowane przez strony, orzekać będzie w sytuacji braku przekonania co do tego, czy obraz zdarzeń ujawniajacy się na tle tych dowodów odpowiada prawdziwemu przebiegowi zdarzeń ${ }^{17}$. Twierdzi się także, że „w czystym modelu kontradyktoryjnego procesu zwycięży ta strona, która zdoła dowieść swych racji i przekonać do nich sąd jako bezstronnego arbitra, a nie ta, która obiektywnie ma rację"18. Obawy te jednak sa nietrafne. Wydaje się bowiem, że to właśnie ten sposób prowadzenia procesu zachęci strony do większej aktywności i przejęcia inicjatywy dowodowej ${ }^{19}$. W końcu nie można także zapominać, że „osiąaniu prawdy materialnej, jako warunku realizacji zasady trafnej represji, nie sprzyja model obecny, albowiem przy braku jakiejkolwiek aktywności ze strony oskarżyciela publicznego, zmusza sąd do poszukiwania dowodów umożliwiajacych wydanie wyr. skazujaccego" "20. Także i w tym względzie w zagwarantowanej w art. $167 \S 1$ k.p.k. inicjatywie dowodowej dla sądu (,w wyjątkowych i szczególnie uzasadnionych wypadkach”) upatrywać należy recepty na problemy, jakie moga pojawić się wraz z wprowadzeniem nowego modelu. Z kolei pewnym ułatwieniem dla występującego przed sądem prokuratora może być nowela art. 333 § 1 k.p.k., nakładajaca na oskarżyciela obowiązek sporządzania sformalizowanego wykazu dowodów (zawierających tezy dowodowe), o których przeprowadzenie wnosi. Niewatpliwie wykaz ten będzie stanowił wytyczne i kierunki postępowania dowodowego w sprawie rozpoznawanej przed sądem.

${ }_{16}$ P. Kowalski, Zasada kontradyktoryjności procesu karnego w świetle projektu Komisji Kodyfikacyjnej prawa karnego, „Palestra” 2012, nr 7-8, s. 75. Autor proponuje następująca treść art. 167 § 1 zd. 2 k.p.k.: „Sąd może jednak wyjątkowo dopuścić dowód z urzędu, jeżeli nieprzeprowadzenie dowodu mogłoby skutkować rażącą niesprawiedliwością wyr. na niekorzyść oskarżonego".

17 Chybione jest tutaj przerzucanie obowiązku wynikającego z art. 2 § k.p.k. na oskarżyciela publicznego. W literaturze pojawił się bowiem pogląd, że „zgodnie z art. 2 ustawy z 20 czerwca 1985 r. o prokuraturze to ona, jako organ nadzorujący działania dochodzeniowo-śledcze innych jednostek, ma strzec praworządności. Prokurator jest przy tym zobowiązany do podejmowania działań należących do zakresu jego zadań, kierując się zasadą bezstronności i zapoznając się z dowodami przemawiającymi tak na niekorzyść sprawcy, jak też na jego korzyść (art. 7 powołanej ustawy)". Zob. P. Kowalski, op. cit., s. 75.

18 Opinia Rady Głównej Związku Zawodowego Prokuratorów i Pracowników Prokuratury RP w sprawie projektu zmian k.p.k. opracowanego przez Komisję Kodyfikacyjną Prawa Karnego z 25 stycznia 2012 r. - wersji po poprawkach legislacyjnych, s. 19.

19 Podobnie P. Hofmański, op. cit., Warszawa 2013, s. 37.

${ }^{20}$ Uzasadnienie Projektu o zmianie ustawy..., s. 15. 
Ze względu na wspomnianą zasadę i jej znaczenie dla oceny nowego modelu procesu na uwagę zasługują także rozważania dotyczące samej istoty i pojęcia wyrażonej w art. $2 \S 2$ k.p.k. zasady prawdy materialnej, które zintensyfikowały się w ramach dyskusji nad projektem nowelizacji k.p.k. Rozważania te prowadzą w konsekwencji do wyłonienia się dwóch skrajnych i rozbieżnych sposobów wykładni tego pojęcia. Z jednej strony przyjmuje się bowiem, że zasada prawdy obiektywnej jest zasadą naczelna, niedopuszczającą żadnych wyjątków $^{21}, \mathrm{z}$ drugiej natomiast - postuluje się, by na gruncie art. $2 \S 2$ k.p.k. posługiwać się pragmatycznym ujęciem prawdy, zrelacjonowanym do określonych w k.p.k. procedur dowodowych, ponieważ przepis ten wbrew powszechnej opinii wyraża zasadę prawdy sądowej, pojmowanej pragmatycznie ${ }^{22}$. W mojej ocenie, to ostatnie stanowisko, zgodnie z którym prawda obiektywna musi być odróżniana od prawdy sądowej, zasługuje na aprobatę, jeżeli weźmiemy pod uwagę, że jej celem jest zobligowanie ustawodawcy do takiego ukształtowania procedury, by zapewniała największą efektywność ustalania prawdy (na poziomie konstytucyjnym) oraz obligowała sąd do takiego jej zastosowania, aby przyjęte za podstawę rozstrzygnięcia ustalenia faktyczne były zbieżne z rzeczywistym stanem rzeczy (na poziomie stosowania prawa) ${ }^{23}$. Przyjęcie takiego znaczenia tej zasady prowadzi także do tego, że wysuwane obawy, czy uda się pogodzić zasadę kontradyktoryjności z zasadą prawdy materialnej, nie maja już takiego znaczenia.

$\mathrm{Na}$ tym tle pewne zastrzeżenia budzi jednak pozostawienie obecnej treści art. 170 k.p.k., który reguluje podstawy oddalenia wniosków dowodowych. Warto zauważyć, że przepis ten miał już swój odpowiednik w ustawie Kodeks postępowania karnego z 1969 r., a więc w czasach, w których o potrzebie wprowadzenia kontradyktoryjności w ogóle nie było mowy. Wydaje się zatem, że w przypadku postępowania kontradyktoryjnego ustawodawca powinien zrezygnować z niedookreślonych i ocennych kryteriów umożliwiających oddalenie wniosku dowodowego, które przyjęte były w postępowaniu inkwizycyjnym. Tym bardziej że za powyższym przemawia słabsza sytuacja procesowa oskar-

21 B. Nita, A. Światłowski, Kontradyktoryjny proces karny (między prawda materialna a szybkościa postepowania), „Państwo i Prawo” 2012, z. 1.

${ }_{22}$ P. Kardas, Zasada prawdy materialnej $w$ perspektywie korespondencyjnej, koherencyjnej, pragmatycznej $i$ konsensualnej teorii prawdy (kilka uwag na tle propozycji nowego ujęcia przepisów dotyczacych postepowania dowodowego przed sqdem pierwszej instancji oraz postepowania dowodowego $w$ toku postęowania przygotowawczego), w: P. Wiliński (red.), op. cit., s. 174-202. W piśmiennictwie znaleźć można stanowisko, zgodnie którym przyjęty sposób definiowania zasady prawdy prowadziłby do uznania niektórych regulacji, tradycyjnie przyjmowanych za wyrażające zasadę prawdy za zbędne. Autor tego poglądu wskazuje, że: „gdyby wszak istotnie art. 2 $\S 2$ k.p.k. miał ustanawiać zasadę, że podstawą rozstrzygnięć powinny być ustalenia faktyczne poczynione zgodnie z obowiąujacca procedura, to znaczyłoby to ni mniej, ni więcej tylko tyle, że sąd powinien w toku dochodzenia do ustaleń faktycznych przestrzegać obowiązującej w tym zakresie procedury. Do tego zaś sąd, jak każdy inny organ państwa, jest obowiązany na podstawie art. 7 Konstytucji”. Zob. J. Majewski, Uwagi o przewidywanym wptywie projektowanych zmian w przepisach o postepowaniu jurysdykcyjnym na możliwości realizacji zasady prawdy materialnej - głos w dyskusji, w: J. Giezek, A. Malicki (red.), Adwokatura jako uczestnik procesu legislacyjnego, Warszawa 2012, s. 101.

23 P. Kardas, op. cit., s. 193-194. 
żonego, który w postępowaniu przygotowawczym będzie miał ograniczone możliwości udowodnienia swojej niewinności.

$\mathrm{Z}$ pełną aprobatą należy odnieść się do zmian wprowadzonych w treści art. 321 k.p.k. Umożliwienie pokrzywdzonemu dostępu do akt postępowania przygotowawczego oczywiście musiało być wprowadzone, chociażby z uwagi na wymóg przyznania równych praw w procesie, wynikający z naczelnej zasady kontradyktoryjności postępowania karnego. Zgodnie z nową treścią tego przepisu pokrzywdzony będzie miał wpływ na zebrany na tym etapie postępowania materiał dowodowy, skoro ustawodawca przyznaje mu prawo do złożenia - w terminie 3 dni od daty zaznajomienia się z aktami - wniosku o uzupełnienie postępowania. Nie podzielam obaw przeciwników tej zmiany, według których regulacja ta może przyczynić się do przedłużenia postępowania, chociażby w sytuacji gdy w sprawie występuje kilku pokrzywdzonych. Nawet jeśli sytuacje takie będą w praktyce miały miejsce, to za nadrzędne należy tu uważać zapewnienie tej istotnej dla kontradyktoryjności gwarancji, w przeciwnym razie wprowadzenie nowego modelu nie miałoby większego sensu. W związku z tym na uznanie zasługuje rozbudowanie i wzmocnienie uprawnień procesowych pokrzywdzonego, w szczególności ustawowe uregulowanie obowiązku poinformowania pokrzywdzonego o uprawnieniach i obowiązkach (art. 300 $\S 2$ k.p.k.). Słuszne są uwagi, że nowela ta stanowi realizację zasady fair trial w odniesieniu do pozycji pokrzywdzonego, ponieważ w sposób decydujacy zwiększa jego uprawnienia ${ }^{24}$.

Pożądana wydaje się jednak także nowelizacja art. 54 § 1 k.p.k., tak aby pokrzywdzony był strona postępowania sądowego, a więc uzyskał status oskarżyciela posiłkowego automatycznie w momencie wniesienia aktu oskarżenia (wniosku o warunkowe umorzenie postępowania karnego itp.) ${ }^{25}$. Obecne rozwiązanie, zawierające wymóg złożenia dodatkowego oświadczenia od pokrzywdzonego zainteresowanego nabyciem uprawnień strony w postępowaniu sądowym, nie znajduje żadnego uzasadnienia merytorycznego, a jednocześnie pozbawia pokrzywdzonego, który nie wypełnił tego obowiązku w terminie, doniosłych uprawnień procesowych.

Oczywiste jest, że zmiany dotyczące postępowania przygotowawczego mogły pójść w innym kierunku. Tytułem przykładu można by tu przywołać postulaty opowiadające się za wprowadzeniem czynnika sądowego w postaci sędziego śledczego ${ }^{26}$. Zdaniem zwolenników tej instytucji usunięcie

${ }^{24}$ P. Kruszyński, M. Zdrojewska, op. cit., s. 59 i cytowana tam literatura dotycząca związku zasady fair trial z zagwarantowaniem pokrzywdzonemu jego praw, m.in.: S. Zappala, Human Rights in International Criminal Proceedings, Oxford-New York 2005, s. 224-225; S. Marks, A. Clapham, International Human Rights Lexicon, Oxford-New York 2005, s. 160-161; A. Sanders, R. Young, Criminal Justice, wyd. 3, Oxford-New York 2007, s. 38-39. P. Kruszyński, M. Zdrojewska, op. cit., s. 59.

${ }^{25}$ Zgodnie z art. $299 \S 1$ k.p.k. w postępowaniu przygotowawczym pokrzywdzony jest strona, obecna zaś treść art. 54 § 1 k.p.k. uzależnia nabycie przez niego statusu strony postępowania od złożenia oświadczenia procesowego.

${ }^{26}$ Instytucja sędziego śledczego wprowadzona została przez Kodeks postępowania karnego z 1928 r. i funkcjonowała w polskim procesie karnym do 1949 r. W latach osiemdziesiątych ubiegłego stulecia pojawiły się jednak pierwsze głosy opowiadające się za wprowadzeniem tej instytucji do polskiej ustawy. Dyskusja na ten temat rozgorzała na nowo na przełomie lat 2007 i 2008, kiedy 
z polskiego modelu postępowania przygotowawczego sędziego śledczego i przekazanie jego uprawnień prokuratorowi doprowadziło do poważnych naruszeń podstawowych praw i swobód obywatelskich, chociażby dlatego, że o stosowaniu tymczasowego aresztowania przestał orzekać niezawisły sędzia, lecz nieposiadający tego atrybutu prokurator ${ }^{27}$. W ocenie części doktryny wprowadzenie sędziego śledczego pozwoliłoby więc na wzmocnienie uprawnień i gwarancji stron postępowania przygotowawczego (w szczególności podejrzanego $)^{28}$.

Model przyjęty przez ustawodawcę wydaje się jednak lepszym rozwiazaniem, chociażby dlatego, że nie naraża prokuratury na zbyt rewolucyjne zmiany, o czym może świadczyć następujący fragment uzasadnienia projektu: „propozycji ukształtowania nowego modelu kontradyktoryjnego postępowania sądowego nie towarzyszą postulaty gruntownych zmian modelowych w obrębie postępowania przygotowawczego" 29 . Nie można także pominąc argumentów, które przemawiają przeciwko wprowadzeniu do polskich rozwiązań instytucji sędziego śledczego. Nie ulega wątpliwości, że prowadzenie postępowania przygotowawczego przez sędziów śledczych byłoby zbyt dużym obciążeniem kadrowym dla polskiego wymiaru sprawiedliwości, który i tak obciążony jest dużą ilością pracy. W doktrynie pojawiały się głosy, że takie zmiany wiązałyby się z wyłączeniem sędziów z procesu orzekania lub koniecznością przekształcenia części etatów prokuratorskich w sędziowskie ${ }^{30}$. Wreszcie, można znaleźć stanowisko, zgodnie z którym wprowadzenie omawianej instytucji jest sprzeczne z realizacja przez sędziego funkcji orzekania oraz wprowadza element inkwizycyjności do procesu karnego ${ }^{31}$. W szczególności warto tu wspomnieć o zorganizowanym przez Instytut Maxa Plancka w 1992 r. we Fryburgu

rozpoczęła się dyskusja na temat odpolitycznienia prokuratury. Za wprowadzeniem niezależnego organu do postępowania przygotowawczego opowiadała się także Krajowa Rada Sądownictwa w uchwale nr 177/2007 z 7 listopada 2007 r. w sprawie potrzeby zmian w organach prokuratury i przywrócenia instytucji sędziego śledczego, „Biuletyn Informacyjny” 2007, nr 14, s. 112. Szerzej o tej instytucji: C. Kulesza, Sędzia śledczy w modelu postepowania przygotowawczego na tle prawnoporównawczym, Białystok 1991; K. Eichstaedt, Rola sadu w postepowaniu przygotowawczym a instytucja sędziego śledczego, Warszawa 2009. Zob. także: A. Zoll, Potrzeba reformy prokuratury, instytucja sędziego śledczego, Materiaty pokonferencyjne - Dobro Rzeczpospolitej niechaj będzie najwyższym prawem, Warszawa, 14 grudnia 2007 r., s. 21-25. Także ostatnio pojawiły się głosy opowiadające się za wprowadzeniem tej instytucji. W jednej z publikacji komentujących nowelizację czytamy: „Autorzy wyrażają głębokie przekonanie, że do idei sędziego do spraw postępowania przygotowawczego należy powrócić w przyszłości w ramach kompleksowej reformy polskiego wymiaru sprawiedliwości, obejmującej nowe spojrzenie na rolę, strukturę i zadania policji, prokuratury oraz sądownictwa”. Zob. P. Kruszyński, M. Zdrojewska, op. cit., s. 58.

27 Zgodnie z tym postulatem pożądane jest, by podmiot, który prowadzi śledztwo, wyposażony był w niezawisłość, a nie tylko niezależność, jak ma to miejsce w przypadku prokuratorów. Zob. K. Eichstaedt, op. cit., s. 11 i 235.

28 Ibidem, s. 234.

29 Uzasadnienie Projektu ustawy o zmianie ustawy..., s. 8.

${ }^{30}$ K. Eichstaedt, op. cit., s. 239.

31 A. Choroszewski, P. Starzyński, Sqd jako dominus Elitis postepowania przygotowawczego, w: S. Lelental, J. Kudrelek, I. Nowicka (red.), Czynności dochodzeniowo-śledcze i działania operacyjne policji a rola sqdu w postęowaniu przygotowawczym, Szczytno 2008, s. 87. 
międzynarodowym sympozjum, na którym postulowano likwidację zbędnego formalizmu oraz instytucji tzw. śledztwa sądowego ${ }^{32}$.

Z kolei korzystnie należy ocenić zmiany w zakresie postępowania dowodowego - wprowadzenie art. 168a k.p.k., zgodnie z którym niedopuszczalne będzie przeprowadzenie i wykorzystanie dowodu uzyskanego do celów postępowania karnego za pomoca czynu zabronionego. Obecnie w polskim prawie karnym nie obowiąuje ${ }^{33}$ reguła, mająca fundamentalne znaczenie w prawie amerykańskim, w myśl której niedopuszczalne jest korzystanie z rzeczowych i osobowych środków dowodowych zebranych w sposób nielegalny, zwana „doktryną owoców zatrutego drzewa" (entrapment) ${ }^{34}$. Dowodem może być wszystko, co umożliwia wyrobienie sobie przekonania sądu o winie lub niewinności oskarżonego ${ }^{35}$. W doktrynie przeważyła koncepcja autonomicznej legalności czynności dowodowych, zgodnie z którą dowody uzyskane w czasie procesu powinny być traktowane niezależnie od legalności innych czynności dowodowych, jeżeli same były wynikiem czynności dowodowych zgodnych z prawem ${ }^{36}$. Stąd też przyjmuje się $e^{37}$, że materialna bezprawność działań organów proceso-

${ }^{32}$ Pomimo że instytucja sędziego śledczego istnieje we Francji od czasów Napoleona, to w ostatnich latach i tam pojawiły się głosy opowiadające się za jej likwidacją. W pewnym stopniu do takiego stanu rzeczy przyczyniła się tzw. afera Outreau, w wyniku której okazało się, że młody sędzia śledczy doprowadził do uwięzienia kilkunastu niewinnych ludzi.

${ }^{33}$ S. Waltoś, Owoce zatrutego drzewa. Procesy $i$ wydarzenia, które wstrzasnęty prawem, Kraków 1978, s. 237.

${ }^{34}$ Powstanie tej koncepcji należy upatrywać w sprawie Weeks v. United States, 232 U.S. 383 (1914), w której SN USA sformułował zasadę wyłączania dowodów (exclusionary rule), zakazująca uzyskiwania dowodów z pogwałceniem IV poprawki do konstytucji, chroniącej obywateli przed nieuzasadnionymi rewizjami i konfiskatami. Postanowienia sprawy Weeks odnosiły się tylko do prawa federalnego. Regułę wyłączenia dowodów na prawo stanowe rozciagnęła sprawa Mapp v. Ohio, 367 U.S. 643 (1961), w której policja dokonała rewizji bez nakazu sądowego, uniemożliwiając przy tym wejście do domu adwokatowi. Nie tylko bezprawne rewizje zostały objęte rygorem wyłączania nielegalnie uzyskanego dowodu. Rygor ten stopniowo rozciagnięto na nielegalny podsłuch (Katz v. United States, 389 US 347), na identyfikację oskarżonego z naruszeniem istotnych reguł przeprowadzania takiej czynności (United States $v$. Wade, 388 US 218), na przesłuchanie podejrzanego przez policję bez zagwarantowania mu prawa do wiadomości o zarzucanym mu przestępstwie, pouczenia o prawie odmowy odpowiedzi i prawie korzystania z porady i obecności obrońcy w czasie przesłuchania (Escobedo v. Illinois, 378 v. 478 z 1963 r., Miranda v. Arizona 86 S.C. 1602 z 1966 r.; Orozco v. State of Texas 384 US 436 z 1969 r.). H.R. Uviller, The Process of Criminal Justice: Investigation, West Publ. Co, St. Paul 1984; T. Tomaszewski, Proces amerykański. Problematyka śledcza, Torun 1996.

${ }^{35}$ Stanowisko to jest zgodne z postanowieniem Sądu Najwyższego z 14 listopada $2006 \mathrm{r}$., zgodnie z którym „obowiązująca procedura karna nie wprowadza żadnego zamkniętego katalogu dowodów, uznając za takie wszystko, co może przyczynić się do wyjaśnienia prawdy [...] nieznany jest tej procedurze zakaz wykorzystania dowodów określanych w literaturze procesowej jako \{owoce zatrutego drzewa\}" - V KK 52/06.

${ }^{36}$ W literaturze przedmiotu zwraca się uwagę, że ustawodawca - zarówno w k.p.k. z 1969 r., jak i w k.p.k. z 1997 r. - świadomie uchylił się od uregulowania kwestii dopuszczalności wykorzystania dowodów „pośrednio nielegalnych” w procesie karnym, pozostawiając ją uznaniu osób prowadzących postępowanie w sprawach karnych. Tak: B. Kurzępa, Podstęp $w$ toku czynności karnoprocesowych $i$ operacyjnych, Toruń 2003, s. 90-91. Pojawiały się jednak postulaty de lege ferenda głoszace potrzebę wprowadzenia regulacji ustawowej w tym zakresie. Zob. Z. Kwiatkowski, Zakazy dowodowe w procesie karnym, Kraków 2005, s. 455.

${ }^{37}$ L. Morawski, Argumenty, racjonalność prawa i postępowanie dowodowe, Toruń 2001, s. 204 i powołane tam poglądy doktryny. 
wych lub czynności dowodowych nie powoduje procesowej niedopuszczalności uzyskanych na tej podstawie dowodów. I tak naruszenie przepisów prawa materialnego, np. na skutek włamania (art. $279 \S 1$ k.k.) w czasie dokonywania czynności dowodowych przeszukania, powoduje wyłącznie opartą na normach tego prawa odpowiedzialność karna, ewentualnie cywilna, dyscyplinarna lub służbową danego podmiotu ${ }^{38}$, gdyż teza, że - na gruncie obowiązujących przepisów - dowód materialnie bezprawny jest dowodem procesowo niedopuszczalnym, nie znajduje oparcia w przepisach karnoprocesowych. Analiza orzecznictwa europejskiego pokazuje ${ }^{39}$, że do jednolitej linii orzecznictwa europejskiego właściwa jest koncepcja całościowego traktowania procesu, a nie jego poszczególnych elementów, jak to przewiduje amerykańska koncepcja „owoców zatrutego drzewa”. Wydaje się jednak, że co prawda organy strasburskie odcinają się od problematyki dopuszczalności dowodów nielegalnych i wykorzystania wyników takiego postępowania dowodowego, niemniej jednak dodanie art. 168a k.p.k. było szczególnie pożądane, ponieważ to właśnie w sferze dowodowej zakotwiczone sa gwarancje praw jednostki w procesie karnym.

Powyższa zmiana jest konsekwencją wprowadzenia w ustawie nowelizujacej odstępstwa od dotychczas obowiązującej zasady, według której na rozprawie sądowej nie wolno odczytywać dokumentów prywatnych powstałych poza postępowaniem karnym i nie dla jego celów (art. $393 \S 3$ k.p.k. a contrario). Rezygnacja ze zwrotu „nie dla jego celów” w sposób zdecydowany umożliwi oskarżonemu „poszukiwanie” dowodów prywatnych jeszcze przed wszczęciem postępowania jurysdykcyjnego. Wraz z wejściem w życie ustawy dopuszczalne będzie odczytywanie wszelkich dokumentów prywatnych powstałych poza postępowaniem karnym, w tym oświadczeń, publikacji, listów czy notatek. Nowe rozwiązanie w pełni koresponduje z nowym modelem procesu karnego i dlatego też należy ocenić tę zmianę za wielce pozytywną. Należy jednak zauważyć, że nowela mogła pójść jeszcze dalej i wprowadzić zmianę w treści art. 174 k.p.k., tak by obrona miała możliwość przeprowadzenia dowodów $\mathrm{z}$ tych odczytywanych dokumentów. Tymczasem zmiany idą w przeciwnym kierunku, nowe brzmienie tego przepisu przewiduje bowiem rozszerzenie zakresu zakazu zastępowania dowodu z wyjaśnień oskarżonego i zeznań świadków, wskazując, że dowody te nie będą mogły być zastępowane, nie tylko - jak obecnie - treścia pism, zapisków lub notatek urzędowych, lecz także innymi dokumentami. Obowiąująca regulacja nakazuje przesłuchania przed sądem osoby reprezentujące jednostki organizacyjne niemające osobowości prawnej lub osoby prawne na okoliczności, o których wiedzę czerpią one jedynie z dokumentów ${ }^{40}$. Wydaje się, że takich sytuacji, w których bezpośrednie przesłuchanie mogło być zastapione dowodem z treści pism, bez uszczerbku dla zasad

${ }^{38}$ Ibidem, s. 205.

${ }^{39}$ Orzeczenie w sprawie Mantovanelli v. Francja z 18 marca 1997 r., skarga nr 21497/93; orzeczenie w sprawie Vidal v. Belgia z 22 kwietnia 1992 r., skarga nr 12351/86; orzeczenie Dumitru Popescu v. Rumunia z 26 kwietnia 2007 r., skarga nr 71525/01; orzeczenie w sprawie Klass i in. v. Niemcy z 6 września 1978 r., skarga nr 5029/71. Szerzej zob. I. Sepioło, Nieobowiazywanie doktryny „owoców zatrutego drzewa” a wytyczne ETPCz, „Palestra” 2010, nr 9-10, s. 226 i n.

${ }^{40}$ Opinia Rady Głównej..., s. 53. 
procesu karnego, mogło być wiele. Nowelizacja w tym kierunku przyczyniałby się również do przyspieszenia postępowania.

Powyższa analiza sprawia, że można pokusić się jednak o stwierdzenie, że wprowadzenie kontradyktoryjności postępowania nie będzie wystarczajace do osiagnięcia celów tej nowelizacji, do których należą przyspieszenie i uproszczenie procedowania w sprawach karnych. W'śód głównych sceptyków ${ }^{41}$ pojawiły się obawy, że eskalacja procesowej rywalizacji spornych stron doprowadzi do nadmiernego przewlekania i wydłużania procesu, np. przez zgłaszanie w nieskończoność wniosków dowodowych. Być może pewnym rozwiąaniem tego problemu będzie jednak pozostawiona - pomimo propozycji jej usunięcia w projekcie Komisji Kodyfikacyjnej - wprowadzona w 2003 r. podstawa oddalenia wniosku dowodowego, przewidziana w art. $170 \S 1$ pkt 5 k.p.k. ${ }^{42}$ Rezygnacja z tego przepisu pozbawiłaby Kodeks postępowania karnego instrumentów dyscyplinowania stron procesu w celu umożliwienia koncentracji materiału dowodowego. Słuszne były obawy zgłaszane do propozycji usunięcia tej podstawy oddalenia wniosku dowodowego ${ }^{43}$. W końcu w praktyce sądowej często dochodzi do stosowania przez oskarżonego (niezainteresowanego szybkim zakończeniem sprawy) tego rodzaju obstrukcji procesowych.

Należy także zauważyć, że przemodelowanie procesu to nie tylko zwiększenie elementów kontradyktoryjnych, ale i również wprowadzenie szerszego zakresu wykorzystania konsensualnych sposobów zakończenia postępowania karnego oraz nowe ujęcie instytucji mediacji ${ }^{44}$. Szczególnie korzystne dla przyspieszenia procesu karnego jest rozszerzenie instytucji wniosku o skazanie bez rozprawy na wszystkie występki (art. $335 \S 1$ k.p.k.) oraz dopuszczalność dobrowolnego poddania się karze w sprawach o wszystkie przestępstwa (art. 387 k.p.k.). Dotychczasowa praktyka pokazała, że instytucje te nawet w obecnym kształcenie prowadzą do szybszego rozstrzygania o kwestii odpowiedzialności karnej. Jednakże należy zgłosić postulat nowelizacji także instytucji ograniczenia przewodu sądowego w trybie art. 388 k.p.k., przez taka jego zmianę, która umożliwiałaby skorzystanie z tej instytucji już w sytuacji

41 Ibidem, s. 8.

${ }^{42}$ W ocenie członków Komisji Kodyfikacyjnej wprowadzona kontradyktoryjność wymaga ograniczenia podstaw oddalanie wniosków dowodowych stron, przez rezygnację z podstawy przewidzianej w art. $170 \S 1$ pkt 5 k.p.k. Za powyższym przemawiało w ocenie Komisji to, że w nowym modelu postępowania sąd zdany jest wyłącznie na inicjatywę dowodową stron.

${ }^{43}$ P. Kowalski, op. cit., s. 77.

${ }^{44}$ Nowela nie tylko wprowadza referendarza sądowego do postępowania karnego, ale także przyznaje mu uprawnienie skierowania sprawy do postępowania mediacyjnego. Na aprobatę zasługuje również wyraźne wskazanie w art. $23 \mathrm{a} \S 7$ k.p.k. zasady bezstronności i poufności prowadzenia mediacji. Podobnie należy ocenić dodanie (po art. 178 k.p.k.) art. 178a k.p.k., który statuuje bezwzględny zakaz dowodowy odnośnie do przesłuchania mediatora co do faktów, o których dowiedział się od oskarżonego lub pokrzywdzonego, prowadząc postępowanie mediacyjne. Wprowadzenie tejże gwarancji było konieczne z uwagi na zalecenia zawarte w dokumentach międzynarodowych, w szczególności w Rekomendacji Komitetu Ministrów Rady Europy nr R (99)19 w sprawie mediacji w sprawach karnych oraz wskazań zawartych w Rekomendacji Komitetu Ministrów Rady Europy nr R (85) 11 w sprawie pozycji ofiary w prawie i procesie karnym. Trudno zatem podzielić pogląd sceptyczny, przekonujący o tym, że nowa regulacja ograniczy naczelną zasadę prawdy materialnej procesu karnego, przez co powinna być wprowadzona. Zob. Opinia Rady Głównej..., s. 30. 
złożenia przez oskarżonego oświadczenia procesowego (w ocenie sądu niebudzącego wątpliwości) w przedmiocie przyznania się do zarzucanego mu czy$n u^{45}$. Niepotrzebnie bowiem obecna treść tego przepisu uzależnia możliwość skorzystania z tej instytucji od złożenia przez oskarżonego wyjaśnień przed sądem. Słusznie w doktrynie wysuwa się także zastrzeżenia do zmiany treści art. 343 k.p.k., którego nowela dopuszcza możliwość uwzględnienia wniosku o skazanie bez rozprawy tylko, jeżeli nie sprzeciwi się temu pokrzywdzony należycie powiadomiony o terminie posiedzenia (art. 343 § 3a k.p.k.). Wydaje się, że pokrzywdzony winien mieć prawo uczestniczenia w negocjacjach między oskarżonym a prokuratorem już na etapie postępowania przygotowawczego. Takie rozwiązanie byłoby korzystne nie tylko z uwagi na przyznanie pokrzywdzonemu szerszych uprawnień, lecz także zapobiegłoby blokowaniu przez niego porozumienia prokuratora i oskarżonego dopiero w postępowaniu jurysdykcyjnym $^{46}$. Natomiast zmiana w art. $343 \S 3 \mathrm{~b}$ k.p.k. przyznajaca uprawnienie sądu do uzależnienia uwzględnienia wniosku od dokonania w nim wskazanej przez sąd zmiany zaakceptowanej przez prokuratora i oskarżonego zasługuje na uwzględnienie. Obecne brzmienie tego przepisu zbyt wąsko zakreśla zakres przedmiotowy takiej modyfikacji i ogranicza ją wyłącznie do możliwości uzależnienia uwzględnienia wniosku jedynie od naprawienia szkody lub od zadośćuczynienia za doznaną krzywdę.

Pewnym sposobem ograniczenia przewlekłości postępowania staje się również nowy model postępowania odwoławczego, który umożliwiać będzie ograniczenie kasatoryjności tego etapu procesu przez szersze orzekanie reformatoryjne $^{47}$. Nie ulega bowiem wattpliwości, że uchylenie wyroku sądu I instancji i przekazanie sprawy do ponownego rozpoznania znacznie wydłuża czas trwania procesu. Przyjęte w noweli rozwiązanie należy oceniać pozytywnie, chociażby ze względu ekonomiki procesowej.

W podsumowaniu powyższego wywodu na temat zmian procedury karnej, które wejdą w życie 1 lipca 2015 r., należy zauważyć, że przyjęte w ustawie modelowe rozwiązanie generalnie zasługuje na aprobatę. Nie ma żadnych racji przemawiajacych za utrzymaniem obecnego modelu postępowania, ponieważ nie ma powodów, dla których dublowanie czynności dowodowych w postępowaniu przygotowawczym i sądowym byłoby konieczne do urzeczywistnienia zasad rzetelnego procesu. $\mathrm{Z}$ drugiej strony reformie tej nie towarzyszy żadne ryzyko wydania niesprawiedliwego wyroku tylko dlatego, że rola sądu zostanie ograniczona jedynie do biernego arbitra. Ustawodawca wprowadził bowiem szereg „furtek” (np. pozostawiając sądowi inicjatywę dowodową w wyjątkowych wypadkach), które dają gwarancję uniknięcia sytuacji, że sąd orzekać będzie bez przekonania, zdany jedynie na dowody prezentowane przez strony. Niemniej tak gruntownej zmianie modelu postępowania karnego winna

\footnotetext{
${ }^{45}$ Opinia Rady Głównej..., s. 57 i n.

${ }^{46}$ P. Kruszyński, M. Zdrojewska, op. cit., s. 64.

${ }^{47}$ Szerzej zob. C. Kulesza, Kontradyktoryjność postępowania odwoławczego w świetle projektu nowelizacji kodeksu postepowania karnego Komisji Kodyfikacyjnej z dnia 8 listopada 2012 r. (druk sejmowy $n r$ 870), w: P. Wiliński (red.), op. cit., s. 105-137.
} 
towarzyszyć równie gruntowna analiza polskiego wymiaru sprawiedliwości, w szczególności ustroju i regulaminu funkcjonowania prokuratury, aby uzyskać pełną kompatybilność wprowadzonego rozwiązania z całym funkcjonującym systemem prawnym.

\author{
dr Iwona Sepioto \\ Uniwersytet im. Adama Mickiewicza w Poznaniu \\ isepiolo@amu.edu.pl
}

\author{
MODEL OF AN ADVERSARY CRIMINAL TRIAL SYSTEM IN LIGHT \\ OF THE AMENDMENTS TO THE CODE OF CRIMINAL PROCEDURE \\ OF 27 SEPTEMBER 2013
}

\begin{abstract}
Sum mary
On 1 July 2015 the Act Amending the Code of Criminal Procedure and certain other laws adopted on 27 September 2013 will come into force. Its main purpose was to transform the existing criminal proceedings from inquisitorial to more adversarial allowing for conducting preparatory proceeding in a manner enabling an adversarial trial. The main amendments to the Code, and in particular those implemented in articles 297 and 167 are discussed. The amendments modify the tasks of the preparatory proceeding limiting them now to a scope only necessary for preparation of a private accusation. The new model is based on an assumption that the presentation evidence and, in consequence the responsibility for the result of the proceeding has been moved from the court onto the parties to the proceeding. This new solution is to be reflected in the new wording of article 167 of the Code, providing that in all proceedings instigated by a party thereto (both in public and private claims) the evidence is the responsibility of the interested party.
\end{abstract}


Copyright of Journal of Law, Economics and Sociology is the property of Faculty of Law and Administration of Adam Mickiewicz University in Poznan and its content may not be copied or emailed to multiple sites or posted to a listserv without the copyright holder's express written permission. However, users may print, download, or email articles for individual use.

Właścicielem praw autorskich do „Ruchu Prawniczego, Ekonomicznego i Socjologicznego” jest Wydział Prawa i Administracji Uniwersytetu im. Adama Mickiewicza w Poznaniu. Zawartość czasopisma nie może być kopiowana, przesyłana do innych stron internetowych bądź zamieszczana na blogach bez pisemnej zgody wydawcy. Niemniej artykuły można drukować, kopiować lub przesyłać w formie elektronicznej na własny użytek. 